\title{
Development of antennal sensilla of Tetragonisca angustula Latreille, 1811 (Hymenoptera: Meliponini) during pupation
}

\author{
V. T. Dohanik ${ }^{a}$, E. A. Souza ${ }^{b *}$, L. C. O. Lisboa ${ }^{b}$, J. C. Zanuncio ${ }^{c}$ and J. E. Serrão ${ }^{a}$ \\ ${ }^{a}$ Departamento de Biologia Geral, Universidade Federal de Viçosa - UFV, CEP 36570-000, Viçosa, MG, Brazil \\ 'Instituto de Ciências Biológicas e da Saúde, Universidade Federal de Viçosa - UFV, Campus Rio Paranaíba, \\ Rodovia MG 230, Km 7, CEP 38810-000, Rio Paranaíba, MG, Brazil \\ 'Departamento de Entomologia, Universidade Federal de Viçosa - UFV, CEP 36570-000, Viçosa, MG, Brazil \\ *e-mail: edmilson.souza@ufv.br
}

Received: August 12, 2015 - Accepted: February 25, 2016 - Distributed: May 31, 2017

(With 2 figures)

\begin{abstract}
The antennal sensilla are sensory organs formed by a group of neurons and accessory cells, which allow perception of environmental cues, which play a role as mechanoreceptors and chemoreceptors. This study describes the post-embryonic development of the antennal sensilla of the stingless Tetragonisca angustula (Hymenoptera: Meliponini) workers. The development of the antennal sensilla begins in the transition stage of the pre-pupae to white-eyed pupae. The sensilla are completely developed at the black-eyed pupae stage, but they are covered by the old cuticle. The sensilla are exposed to the environment only in newly emerged workers of $T$. angustula, but it is possible that environmental stimuli can be recognized due to the pores in the old cuticle.
\end{abstract}

Keywords: placoid sensilla, trichodea sensilla, stingless bee, pupal development.

\section{Desenvolvimento das sensilas antenais de Tetragonisca angustula latreille, 1811 (Hymenoptera: Meliponini) durante a pupação}

\section{Resumo}

As sensilas antenais são órgãos sensoriais formados por um conjunto de neurônios que captam estímulos ambientais e células acessórias, desempenhando as funções de mecanorreceptores e quimiorrecepterores. Este trabalho descreve o desenvolvimento pós-embrionário das sensilas antenais de operárias das abelhas sem ferrão Tetragonisca angustula (Hymenoptera: Meliponini). O desenvolvimento das sensilas tem início na transição de pré-pupa para pupa de olho branco e estão completamente desenvolvidas no estágio de pupa de olho preto, mas ainda estão cobertas pela cutícula velha. As sensilas estão completamente expostas em operárias recém-emergidas de T. angustula, mas é possível que estímulos ambientais sejam percebidos em estágios anteriores devido aos poros presentes na cutícula velha.

Palavras-chave: sensila placoide, sensila tricoide, abelha sem ferrão, desenvolvimento pupal.

\section{Introduction}

Bees have different levels of sociability from solitary to highly eusocial, with a complex integration in the colony of behavioral patterns and physiological adaptations (Michener, 1974).

Tetragonisca angustula Latreille, 1811 (Hymenoptera: Meliponini) and other highly eusocial stingless bees display a complex behavior, depending upon the communication among individuals of the colony. Chemical communication is important for the maintenance of the insect society, and products of exocrine glands play a central role in this communication (Monnin, 2006). These secretions function as volatile and non-volatile pheromones (Engels et al., 1993; Katzav-Gozansky et al., 2001; Monnin, 2006).
Pheromones are recognized by sensory organs that are commonly present in the insect antennae. The antennae are important sensory appendages of insects with a large concentration of sensilla, which play a role in perceiving the environmental stimuli (Chapman, 2013).

The sensilla of insects are usually formed by an oligocellular complex with one or more bipolar sensitive neurons associated with accessory thecogen, trichogen, and tormogen cells (Schneider, 1964; Keil, 1997; Euzebio et al., 2013). The thecogen cell envelops the neuron as a sheath for structural and metabolic support. The trichogen cell partially covers the dendrite and is responsible for the production of the sensitive cuticular hair. The basal region 
of the cuticular hair has an elastic protein that is released by the tormogen cell (Schneider, 1964; Keil, 1997).

The sensilla have different morphology. In bees, they are classified into trichoid, basiconic, coeloconic, campaniform, placoid, and ampullaceum types (Schneider, 1964; Fialho et al., 2014; Chapman, 2013; Ravaiano et al., 2014).

The development of the antennae in bees, likely in holometabolous insects, occurs by differentiation of imaginal discs during larvae and pupae development (Snodgrass, 1956). In general, the antennal sensilla develop in the pupal stage (Eichmuller and Schäfer, 1995; Schmidt and Kuhbandner, 1983) when a single precursor cell arises in the epidermal surface and differentiates into neurons and accessory cells, followed by the formation of sensory cuticle structures (Keil, 1997; Ray and Rodrigues, 1995; Azevedo et al., 2008).

Although several studies about the different types of antennal sensilla in bees (Dietz and Humphreys, 1971; Moraes and Cruz-Landim, 1972; Stort and Moraes-Alves, 1999; Al-Ghamdi, 2006), histological analysis of the development of these sensilla in stingless bees was performed only in Melipona quadrifasciata anthidioides (Azevedo et al., 2008). Therefore, the analysis of the development of the antennal sensilla in other species of bees is important to confirm previous data and find new information that contributes to the understanding of these sensory organs. The present study describes the post-embryonic development of the antennal sensilla in the stingless bee Tetragonisca angustula.

\section{Material and Methods}

Workers of $T$. angustula were obtained from colony maintained in Rio Paranaíba, Minas Gerais State, Brazil. Brood combs were transferred to laboratory, and the pupal developmental stages of the bees were determined according to the compound eye colors into white-, pink-, brown-, and black-eyed pupae. Newly emerged adult workers were collected when emerging from the brood cells.

\subsection{Scanning electron microscopy}

The insects were cryoanesthetized and their antennae were removed and transferred into Zamboni's fixative solution (Stefanini et al., 1967), dehydrated in a graded ethanol series, transferred to hexamethyldisilazane (HMDS) for $10 \mathrm{~min}$ and air-dried (Nation, 1983). Then, the antennae were gold-covered (20-nm thick) and analyzed under a scanning electron microscope (LEO VP1430) in the Nucleus of Microscopy and Microanalysis at the Universidade Federal de Viçosa.

\subsection{Light microscopy}

The antennae of T. angustula pupae and adults were dissected and transferred into Zamboni's fixative solution for $4 \mathrm{~h}$. The samples were dehydrated in a graded ethanol series and embedded in historesin (Leica). Sections of 3- $\mu \mathrm{m}$ thickness were stained with toluidine blue and examined under light microscope.

\section{Results}

The antennae of $T$. angustula pupae workers were covered with a larval residual cuticle until the black-eyed stage (Figure 1A). This residual larva cuticle contained some pores (Figure 1B). Trichoid and placoid sensilla were observed in the antennal scapus from the brown-eyed pupae, but best viewed in black-eyed pupae (Figure 1C).

The sensilla of newly emerged workers were completely exposed to the environment, showing the presence of trichoid, placoid and campaniform types (Figure 1D).
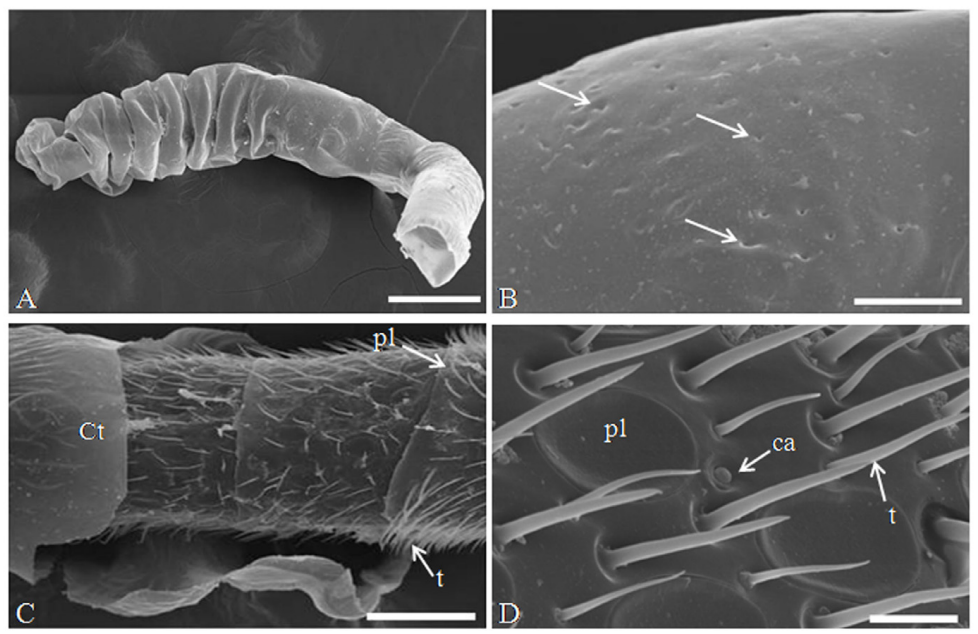

Figure 1. Scanning electron micrographs of the antennae of Tetragonisca angustula (Hymenoptera: Meliponini) worker at different pupa stages. (A) Antennae of white-eyed pupae covered with residual larval cuticle. Bar: $200 \mu \mathrm{m}$. (B) Pores (arrows) in the residual larval cuticle. Bar: $15 \mu \mathrm{m}$. (C) Antenna of black-eyed pupae partially covered by a cuticle with trichoid sensilla in the antennomers. Bar: $50 \mu \mathrm{m}$. (D) Antenna of newly emerged adult showing sensilla trichoid, placoid and campaniform Bar: $7 \mu \mathrm{m}$. Ct: cuticle; t: trichodea sensilla; ca: campaniform sensilla; pl: placoid sensilla. 
The histological analysis of the antennae of white-eye pupae showed the antennal surface without sensilla (Figure 2A-B). In this pupal stage, the antennomers were not individualized, but some had small constrictions, indicating that the antennal segmentation was initiated at this stage (Figure 2A). The neurons had dendrites targeted to the antennal surface and the axons to the lumen, forming the antennal nerve (Figure 2B). The neurons showed large nuclei with decondensed chromatin (Figure 2B).

In the pink-eyed pupae, the antenna had small surface projections, corresponding to the sensilla in the development process (Figure 2C).

The antennal segmentation in antennomers was evident in brown-eyed pupae with the surface projections elongated and showing the development of trichoid sensilla (Figure 2D).
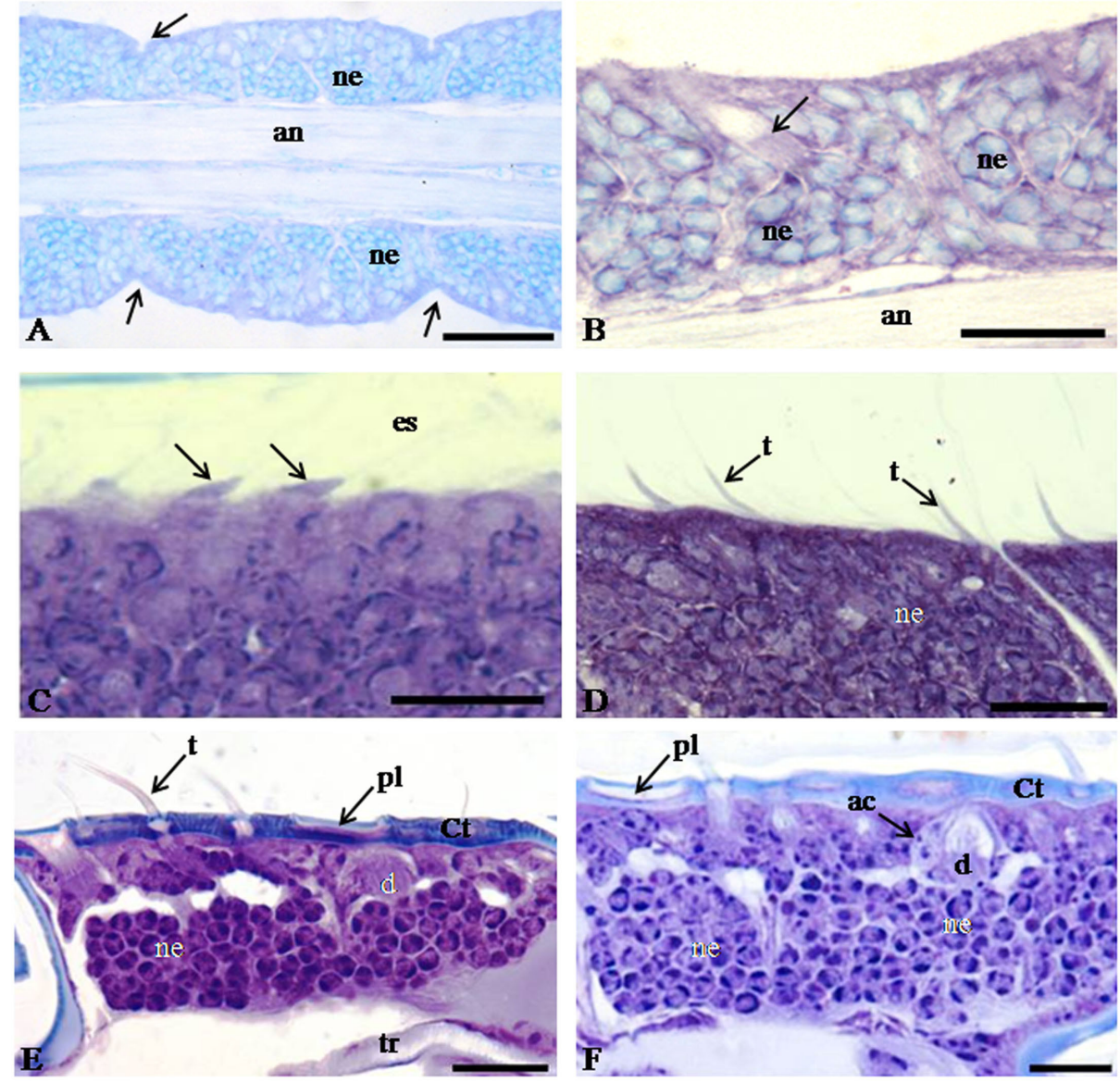

Figure 2. Histological sections of the antennae of Tetragonisca angustula (Hymenoptera: Meliponini) worker at different developmental stages. (A) Antennal segmentation process (arrows) white-eyed pupae. Bar: $30 \mu \mathrm{m}$. (B) Antenna of white-eyed pupae with the surface without sensilla, with dendrites of neurons projecting to the surface of the antenna (arrows) and the antennal nerve. Bar: $15 \mu \mathrm{m}$. (C) Projections of the sensilla in the antennae of pink-eyed pupae. Bar: $20 \mu \mathrm{m}$. (D) Development of trichoid sensilla in the antennae brown-eyed pupae. Bar: $20 \mu \mathrm{m}$. (E) Histological section of the antennae of black-eyed pupae showing neurons and dendrites in the sensilla. Bar: $20 \mu \mathrm{m}$. (F) Histological section of the antennae of newly emerged adult workers of T. angustula (Hymenoptera: Meliponini) showing neurons, dendrites and accessory cells in the sensilla. Bar: $15 \mu \mathrm{m}$. Ct: cuticle; d: dendrite; ac: accessory cells; an: antennal nerve; es: exuvial space; ne: neuron; pl: placoid sensilla; t: trichoid sensilla; tr: trachea. 
present in the antenna of the T. angustula pupae may play a role in gas exchange and enable contact with signaling molecules present in the colony.

The antennal epidermis differentiation has also been reported in Drosophila melanogaster, with the expression of specific genes triggering the onset of the development of neurons and accessory cells (Ray and Rodrigues, 1995). The proneural genes induce the formation of precursor sensory cells, which, on differentiation, inhibit differentiation of the neighboring cells, resulting in the formation of sensillogenic epidermis by lateral inhibition (Campuzano and Modolell, 1992; Keil, 1997).

The development of the antennal sensilla of T. angustula in the early white-eye pupae, which is characterized by presence of neurons with dendrites directed to the antennal surface, is similar to that of Apis mellifera (Eichmuller and Schäfer, 1995) and M. quadrifasciata anthidioides (Azevedo et al., 2008). The differentiation of neurons in white-eyed $T$. angustula pupae suggests that sensilla are in the early developmental stages, forming the sensillogenic region of the epidermis, such as that reported in the pupae of Antherae polyphemus Cramer, 1776 (Saturniidae: Saturniinae) (Keil and Steiner, 1990). The expression of the genes that play some roles in the sensilla differentiation affect the antennal epidermis before the pupal stage (Keil and Steiner, 1990; Keil, 1997).

The presence of neurons and their dendrites in T. angustula before the formation of the sensilla projections has also been reported in M. quadrifasciata anthidioides (Azevedo et al., 2008). The neurons of $A$. polyphemus were detected 2 days after the larva molted to pupae, and the sensilla projections appeared after the third day (Keil and Steiner, 1991).

The cuticle of the adult $T$. angustula probably begins to be deposited after the apolysis of the larva cuticle, and it is complete in the black-eyed pupa. The apical projection of the epidermal cells occurs in the pink eyed pupae, suggest cuticle deposition in this stingless bee. The cuticle that forms the antennal sensilla begins to be deposited by trichogen cells when the sensilla attain its final length (Kuhbandner, 1984; Keil and Steiner, 1991; Keil, 1997).

The early development of antennal sensilla and the differentiation of antennomers in white-eyed pupae and their complete development in black-eyed pupae of $T$. angustula are similar to those of $A$. polyphemus (Keil and Steiner, 1990).

The development of the antennal sensilla in T. angustula begins at early white-eye pupae stage, and it is completed in the black-eyed pupae stage, when the sensilla are capable of detecting colony stimuli.

\section{Acknowledgements}

This research was supported by Brazilian research agencies CNPq, CAPES and FAPEMIG. We are grateful to the Núcleo de Microscopia e Microanálises, Universidade Federal de Viçosa, for technical assistance.

\section{References}

AL-GHAMDI, A.A., 2006. Scanning electron microscopic studies on antennal sensilla organs of adult honey bee workers in genus Apis (Hymenoptera: Apidae). Bulletin of the Entomoligical Society of Egypt, vol. 83, pp. 1-11.

AZEVEDO, D.O., MATIELLO-GUSS, C.P., RÖNNAU, M., ZANUNCIO, J.C. and SERRÃO, J.E., 2008. Post-embryonic development of the antennal sensilla in Melipona quadrifasciata anthidioides (Hymenoptera: Meliponini). Microscopy Research and Technique, vol. 71, no. 3, pp. 196-200. http://dx.doi.org/10.1002/ jemt.20539. PMid:17992691.

CAMPUZANO, S. and MODOLELL, J., 1992. Patterning of the Drosophila nervous system: the achaete-scute gene complex. Trends in Genetics, vol. 8, no. 6, pp. 202-208. http://dx.doi. org/10.1016/0168-9525(92)90234-U. PMid:1496555.

CHAPMAN, R.F., 2013. The insects: structure and function. 5th ed. Cambridge: Cambridge Univ. Press. 929 p.

DIETZ, A. and HUMPHREYS, W.J., 1971. Scanning electron microscopic studies of antennal receptors of the worker honey bee, including sensilla campaniformia. Annals of the Entomological Society of America, vol. 64, no. 4, pp. 919-925. http://dx.doi. org/10.1093/aesa/64.4.919.

EICHMÜLLER, S. and SCHAFER, S., 1995. Sensory neuron development revealed by taurine immunocytochemistry in the honeybee. The Journal of Comparative Neurology, vol. 352, no. 2, pp. 297-207. http://dx.doi.org/10.1002/cne.903520211. PMid:7721996.

ENGELS, E., ENGELS, W., LÜBKE, G., SCHRÖDER, W. and FRANCKE, W., 1993. Age-related patterns of volatile cephalic constituents in queens of the neotropical stingless bee Scaptotrigona postica Latr (Hymenoptera, Apidae). Apidologie, vol. 24, no. 6, pp. 539-548. http://dx.doi.org/10.1051/apido:19930601.

EUZEBIO, D.E., MARTINS, G.F. and FERNANDES-SALOMÃO, T.M., 2013. Morphological and morphometric studies of the antennal sensilla from two populations of Atta robusta (Borgmeier 1939) (Hymenoptera: Formicidae). Brazilian Journal of Biology $=$ Revista Brasileira de Biologia, vol. 73, no. 3, pp. 663-668. http:// dx.doi.org/10.1590/S1519-69842013000300026. PMid:24212709.

FIALHO, M.C.Q., GUSS-MATIELLO, C.P., ZANUNCIO, J.C. and SERRÃO, J.E., 2014. A comparative study of antennal sensilla in corbiculate bees. Journal of Apicultural Research, vol. 53, no. 3, pp. 392-403. http://dx.doi.org/10.3896/IBRA.1.53.3.07.

KATZAV-GOZANSKY, T., SOROKER, V., IBARRA, F., FRANCKE, W., and HEFETZ, A., 2001. Dufour's gland secretion of the queen honeybee (Apis mellifera): an egg discriminator pheromone or a queen signal? Behavioral Ecology and Sociobiology, vol. 51, no. 1, pp. 76-86. http://dx.doi.org/10.1007/s002650100406.

KEIL, T.A. and STEINER, C., 1990. Morphogenesis oh the antenna of the male silkmoth Antheraea polyphemus II. Differential mitoses of "dark" precursor cells create the anlagen of sensilla. Tissue \& Cell, vol. 22, no. 5, pp. 705-720. http://dx.doi.org/10.1016/00408166(90)90066-I. PMid:18620326.

KEIL, T.A. and STEINER, C., 1991. Morphogenesis on the antenna of the male silkmoth Antheraea polyphemus III. Development of olfactory sensilla and the properties of hear-forming cells. Tissue \& Cell, vol. 23, no. 6, pp. 821-851. http://dx.doi.org/10.1016/00408166(91)90034-Q. PMid:18621189. 
KEIL, T.A., 1997. Comparative morphogenesis of sensillas: a review. International Journal of Insect Morphology \& Embryology, vol. 26, no. 3-4, pp. 151-160. http://dx.doi.org/10.1016/S00207322(97)00017-2.

KUHBANDNER, B., 1984. Ultrastructure and ontogeny of the hair sensilla on the funicle of Calliphora erythrocephalla (Insecta: Diptera). Zoomorphology, vol. 104, no. 6, pp. 373-385. http:// dx.doi.org/10.1007/BF00312188.

MICHENER, C.D., 1974. The social behavior of the bees. Cambridge: The Belkman Press of Harvard University Press. 404 p.

MONNIN, T., 2006. Chemical recognition of reproductive status in social insects. Annales Zoologici Fennici, vol. 43, pp. 515-530.

MORAES, R.L.M.S. and CRUZ-LANDIM, C., 1972. Estudo comparativo de órgãos sensoriais em abelhas com diferentes tipos de comunicação. Revista Brasileira de Biologia = Brazillian Journal of Biology, vol. 32, pp. 185-196.

NATION, J.L., 1983. A new method using hexamethyldisilazane for preparation of the soft insect tissues for scaning electron microscopy. Stain Technology, vol. 58, no. 6, pp. 347-351. http:// dx.doi.org/10.3109/10520298309066811. PMid:6679126.

RAVAIANO, S.V., FERREIRA, R.P., CAMPOS, L.A. and MARTINS, G.F., 2014. The antennal sensilla of Melipona quadrifasciata (Hymenoptera: Apidae: Meliponini): a study of different sexes and castes. Naturwissenschaften, vol. 101, no. 8, pp. 603-611. http://dx.doi.org/10.1007/s00114-014-1184-0. PMid:24861136.
RAY, K. and RODRIGUES, V., 1995. Cellular events during development of the olfactory sense organs in Drosophila melanogaster. Developmental Biology, vol. 167, no. 2, pp. 426-438. http://dx.doi.org/10.1006/dbio.1995.1039. PMid:7875369.

SCHMIDT, K. and KUHBANDNER, B., 1983. Ontogeny of the sensilla placodea on the antennae of Aulacus striatus jurine (Hymenoptera: Aulacidae). International Journal of Insect Morphology \& Embryology, vol. 12, no. 1, pp. 43-57. http:// dx.doi.org/10.1016/0020-7322(83)90034-X.

SCHNEIDER, D., 1964. Insect Antennae. Annual Review of Entomology, vol. 9, no. 1, pp. 103-122. http://dx.doi.org/10.1146/ annurev.en.09.010164.000535.

SNODGRASS, R.E., 1956. Anatomy of the honey bee. New York: Comstock Publishing Associate. 334 p.

STEFANINI, M., DEMARTINO, C. and ZAMBONI, L., 1967. Fixation of ejaculated spermatozoa for electron microscopy. Nature, vol. 216, no. 5111, pp. 173-174. http://dx.doi.org/10.1038/216173a0. PMid:4862079.

STORT, A.C. and MORAES-ALVES, M.M.B., 1999. Differences in the number of the antennal sensory structures of males of three honey bee types. Brazilian Journal of Biology $=$ Revista Brasileira de Biologia, vol. 59, no. 1, pp. 161-166. http://dx.doi. org/10.1590/S0034-71081999000100020. 